\title{
A periimplantitis sebészi kezelése air-abrasive technológia alkalmazásával
}

\author{
Esetismertetés
}

DR. IVÁNYI DÓRA, DR. SIMON FANNI, DR. KIVOVICS MÁRTON, DR. GÁNGÓ JÚLIA, DR. NÉMETH ORSOLYA

\begin{abstract}
Az implantációkkal kapcsolatos biológiai szövődmények közé soroljuk a periimplantaris mucositist és a periimplantitist. A periimplantaris gyulladások gyógyulását konzervatív és különböző sebészi beavatkozásokkal is elősegíthetjük, azonban mindegyik kezelési metódus fontos alappillére, hogy a gyulladt periimplantaris szöveteket és az implantátum supraossealis részét megtisztítsuk. A nemzetközi irodalomban számos közlemény vizsgálja a különböző airabrasive rendszerek alkalmazását a periimplantaris gyulladások terápiájában. A hagyományos szilikát alapú porral működő air-abrasive rendszerek nagy hátránya, hogy a periimplantaris szövetek közé került szemcsék nem szívódnak fel. A glicinporral működő, kifejezetten submucosalis tisztításra kifejlesztett rendszernek előnye, hogy a por vizes közegben felszívódik, és kevéssé károsítja az implantátum felszínét.

Jelen tanulmányban olyan eseteket mutatunk be, ahol a periimplantaris gyulladások sebészi kezelése történt, és a beavatkozás közben a glicinporral múködő air-abrasive rendszert (Varios Combi Pro, NSK/Nakanishi Inc., Shimohinata Kanuma, Japán) alkalmaztuk. Bemutatunk két keratinizált mucosa szélesítésével egybekötött és egy keratinizált mucosa szélesítése nélkül végzett nyitott periimplantaris küretet.
\end{abstract}

Kulcsszavak: periimplantitis, peri implant mucositis, air-abrasive, glicinpor, keratinizált mucosa szélesítés, sebészi terápia

A fogászati implantációval kapcsolatos szövődmények az implantációs fogpótlások elterjedésével egyre nagyobb figyelmet kaptak az elmúlt évtizedben. Az implantációval kapcsolatos késői komplikációk közé soroljuk a mechanikai és a biológiai szövődményeket. A biológiai szövődmények közé tartozik a periimplantaris mucositis és a periimplantitis [1]. Az American Academy of Periodontology (AAP) és a European Federation of Periodontology (EFP) 2017-ben tartott workshopján rendszerezték az enossealis implantátumokat körülvevő lágy-, illetve keményszöveti viszonyok jellemzéseit és elváltozásaikat. A periimplantaris szövetek egészségét az implantátum körüli szövetek gyulladásának hiánya határozza meg. Ilyenkor erythema, szondázáskor jelentkező vérzés (Bleeding on Probing, BoP), duzzanat és suppuratio nem jelentkezik. Egészséges állapot kialakítható csontvesztést követően is. A periimplantaris mucositis főbb karakterizációját a szondázáskor jelentkező vérzés adja. Erythema, duzzanat és/vagy suppuratio ilyenkor jelentkezhet. Sokszor a lágy szövetek duzzanata megnövekedett szondázási tasakmélységhez (pocket probing depth, PPD) vezet. A periimplantitist egy olyan plakk-asszociált patológiai állapotnak tekintjük, mikor az implantátum körüli szövetek gyulladását progresszív csontpusztulás kíséri. A periimplantitis klinikai képét mutatja a pozitív BoP és/vagy suppuratio, a kiindulási álla- pothoz képest megnövekedett PPD és/vagy a periimplantaris mucosa recessiója, illetve a radiológiai csontveszteség [2]. (1. táblázat)

A periimplantaris mucositis gyakorisága igen magas, az implantációs protetikával ellátott betegek 64-80\%ánál fordul elő. A periimplantitis az implantátumot kapott betegek 9-20\%-ánál jelentkező kórkép [3-5]. A periimplantaris gyulladások multifaktoriális betegségek, habár a kialakulást elősegítő legnagyobb rizikónak az implantátumok körüli plakk-akkumulációt tekinthetjük [6]. Az implantátumok körüli keratinizált mucosa jelentőségéről szóló tanulmányok szerint valószínüsíthető, hogy a megfelelő mennyiségü és minőségű keratinizált mucosa elősegíti az implantátumok körüli plakk eltávolítását [2]. Tudjuk, hogy az elmozduló mucosa a beszéd, evés, nevetés és ásítás közben minimálisan elemelkedik az implantátumtól, elemelkedés közben a lepedék és az ételmaradékok bepréselődhetnek a sulcusba, és elősegíthetik a plakk okozta gyulladások kialakulását. A nemzetközi irodalomban nagy számban találunk publikációkat, amelyek leírják, hogy magasabb arányban jelentkeznek az implantátum körüli szövetek gyulladásos reakciói olyan esetekben, mikor a keratinizált mucosa szélessége nem megfelelő mértékü (<2 mm) [6]. Kevesebb plakk tud lerakódni azokban az esetekben, amikor az implantátum körül lágyszöveti viszony rendezett, hi- 
A periimplantaris közeg definiálásának kritériumrendszere [2]

(BoP: szondázáskor jelentkező vérzés; PPD: szondázási tasakmélység)

\begin{tabular}{|c|c|c|}
\hline Egészséges periimplantális szövetek & Periimplantaris mucositis & Periimplantitis \\
\hline $\begin{array}{l}\text { - Gyulladás klinikai jeleinek hiánya } \\
\text { - Pozitív BoP és/vagy suppuratio hiánya } \\
\text { - Nincs megnövekedett PPD a korábbi } \\
\text { vizsgálatokhoz képest } \\
\text { - Inicialis csont- átépülésen kívüli } \\
\text { csontpusztulás hiánya }\end{array}$ & $\begin{array}{l}\text { - Pozitív BoP és/vagy suppuratio } \\
\text { - Korábbi vizsgálatokhoz képest } \\
\text { megnövekedett PPD lehetséges } \\
\text { - Inicialis csont-átépülésen kívüli } \\
\text { csontpusztulás hiánya }\end{array}$ & $\begin{array}{l}\text { - Pozitív BoP és/vagy suppuratio } \\
\text { - Korábbi vizsgálatokhoz képest } \\
\text { megnövekedett PPD } \\
\text { - Inicialis csont átépülésen felüli csontpusztulás } \\
\text { Korábbi vizsgálatok eredményeinek hiányában } \\
\text { - Pozitív BoP és/vagy suppuratio } \\
\text { - PPD > } 6 \mathrm{~mm} \\
\text { - Csontszint > } 3 \mathrm{~mm} \text { az implantátum } \\
\text { legcoronalisabb részétől }\end{array}$ \\
\hline
\end{tabular}

szen ilyenkor komfortosabb és könnyebb az implantátumok tisztíthatósága [7]. Megfigyelték, hogy elmozduló mucosa mellett akkor nő meg az implantátum körüli szövetek gyulladásának valószínūsége, amennyiben a páciens nem rendelkezik tökéletes szájhigiéniával [6]. Egyelőre kevés bizonyíték áll fenn arra vonatkozóan, hogy milyen szerepe lehet a papilláknak, a midbuccalis lágyszövet magasságának és a mucosa vastagságának a periimplantaris egészség megőrzésében. A papillák kitöltöttsége fontos szerepet játszhat az esztétikán kívül a pótlások tisztíthatóságában is [8]. A sikeres implantációnak nem előfeltétele a keratinizált mucosa megléte, de jelenléte segíti a környező szövetek ellenállását a dentalis plakkal szemben.

A periimplantaris gyulladások kezelését két fő csoportra bonthatjuk: konzervatív és sebészi terápia. A periimplantaris gyulladások terápiája során az egyik legfontosabb lépés a megfelelő egyéni szájhigiéniás instruálás, motiválás és a plakkretentív tényezők eliminálása. A konzervatív terápia során az implantátumot és a periimplantaris szöveteket professzionális szájhigiéniás eszközökkel zártan megtisztítjuk. Ilyen eszközök lehetnek a polírozó kefék, illetve gumik, a speciálisan implantátumok tisztítására kialakított kézi és gépi depurátorok és küretszettek, a különböző air-abrasive rendszerek és a lézerrel történő tisztítás. Fontos, hogy olyan metódust válasszunk, amely a lehető legkevésbé sérti az implantátum felszínét és a periimplantaris szöveteket [1, 9]. Sebészi terápia során az elsődleges cél a gyulladás megszüntetése, míg másodlagosnak tekinthetjük a periimplantaris szövetek regenerációját. A sebészi terápiát periimplantitis esetében alkalmazzuk, és azt megelőzi a konzervatív terápia. Sebészi terápia során végezhetünk periimplantaris nyitott küretet, resectiv vagy regenerativ sebészi eljárást. Supraossealis defektusok esetében végezhetünk nyitott küretet és resectiv sebészi eljárást. Mindkét esetben mucoperiostealis lebenyképzés mellett eltávolítjuk a gyulladásos szöveteket és az implantátum felszínét megtisztítjuk. Resectiv eljárások célja még az egyenetlen csontszélek elsimítása és a jól tisztítható implantátumok létrehozása. Az implantátumot kö- rülvevő szövetek redukcióján felül implantoplasticát végezhetünk. A szabad csavarmenetek és a porózusra előkezelt felszínek elfinírozása és polírozása miatt a beteg számára az implantátumok könnyebben tisztíthatókká válnak, de az implantátumok mechanikai ellenállása a rágóerőkkel szemben ilyenkor csökken [10-12]. Amennyiben később szükségesnek tartjuk, keratinizált mucosát létrehozó műtéti technikákkal növelhetjük a sebészi terápián átesett periimplantaris szövetek stabilitását. A regeneratív mútétek célja, hogy a periimplantaris defektus csökkenését idézzük elő. A módszer akkor használatos, mikor a defektus részét képezi egy intraossealis komponens. Az implantátum alapos tisztítása után az intraossealis hiányokat kitöltjük csontpótló anyagokkal, és membránnal fedhetjük. A csonthiány regeneratív potenciálját előrevetíti a defektus morfológiája, ami a háromfalú (circumferentialis) tasakok esetében a legkedvezőbb. A regeneratio kiegészítéseként végezhetünk itt is lágyrész augmentatiót [1, 13]. Vannak olyan esetek, amikor az implantátum prognózisa reménytelen, ilyenkor az implantátum eltávolítása a legmegfelelőb kezelés. A periimplantaris gyulladások adekvát kezelésének kiválasztásához Sinjab és munkatársai által készített döntéshozatali fa nyújthat segítséget, amely az implantátum körül kialakuló szövődmények minőségétől függően javasol terápiás lehetőségeket [14]. (1. kép)

Jelen tanulmányban olyan eseteket mutatunk be, ahol a periimplantaris gyulladások sebészi terápiáját egy glicinporral múködő air-abrasive technika (Varios Combi Pro, NSK/Nakanishi Inc., Shimohinata Kanuma, Japán) kiegészítésével végeztük. A szakirodalom szerint az airabrasive technika alkalmas a szennyezett implantátumfelületek dekontaminálására. A supramucosalis részek tisztítására használatos szilikát alapú porok vizes közegben nem szívódnak fel, tehát alkalmazásuk submucosalisan nem szerencsés, hiszen az apró szemcséket nem tudjuk maradéktalanul eltávolítani. A Varios Combi Pro alkalmazása során egy egyszer használatos speciális műanyag fúvókán keresztül, állítható nyomáson, vízoldékony glicinport tudunk az implantátum felszínére juttatni, ami mechanikusan tisztítja azt. Használat során 

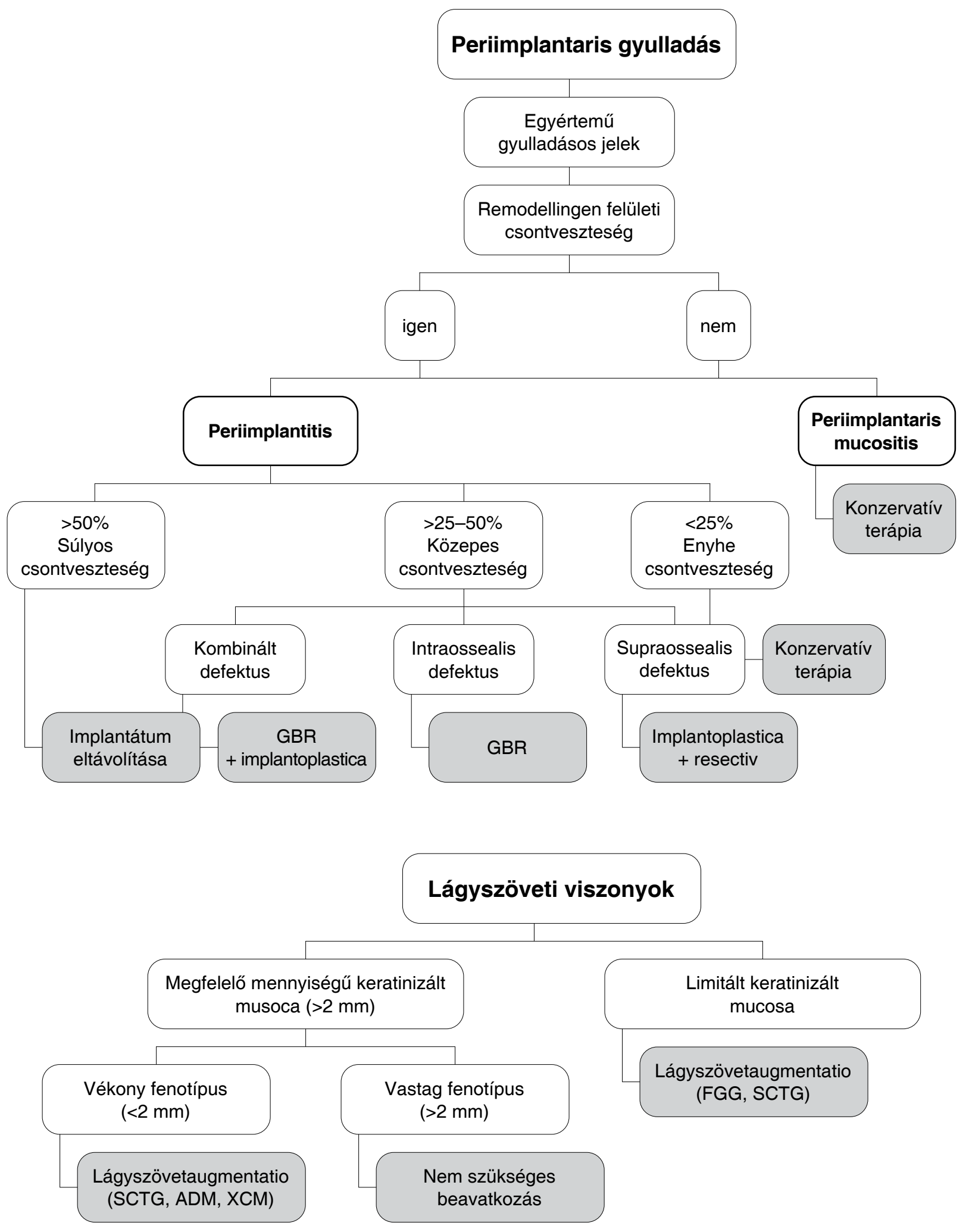

1. kép: Sinjab és munkatársai publikációja alapján készült döntéshozatali fa segítséget nyújthat az implantációval kapcsolatos biológiai szövődmények megfelelő terápiájának kiválasztásánál [14]

GBR: irányított csontregeneració (guided bone regeneration); SCTG: subcutan kötőszöveti graft (subcutan connective tissue graft); ADM: acellularis dermalis mátrix; XCM: xenogen kollagén mátrix) 

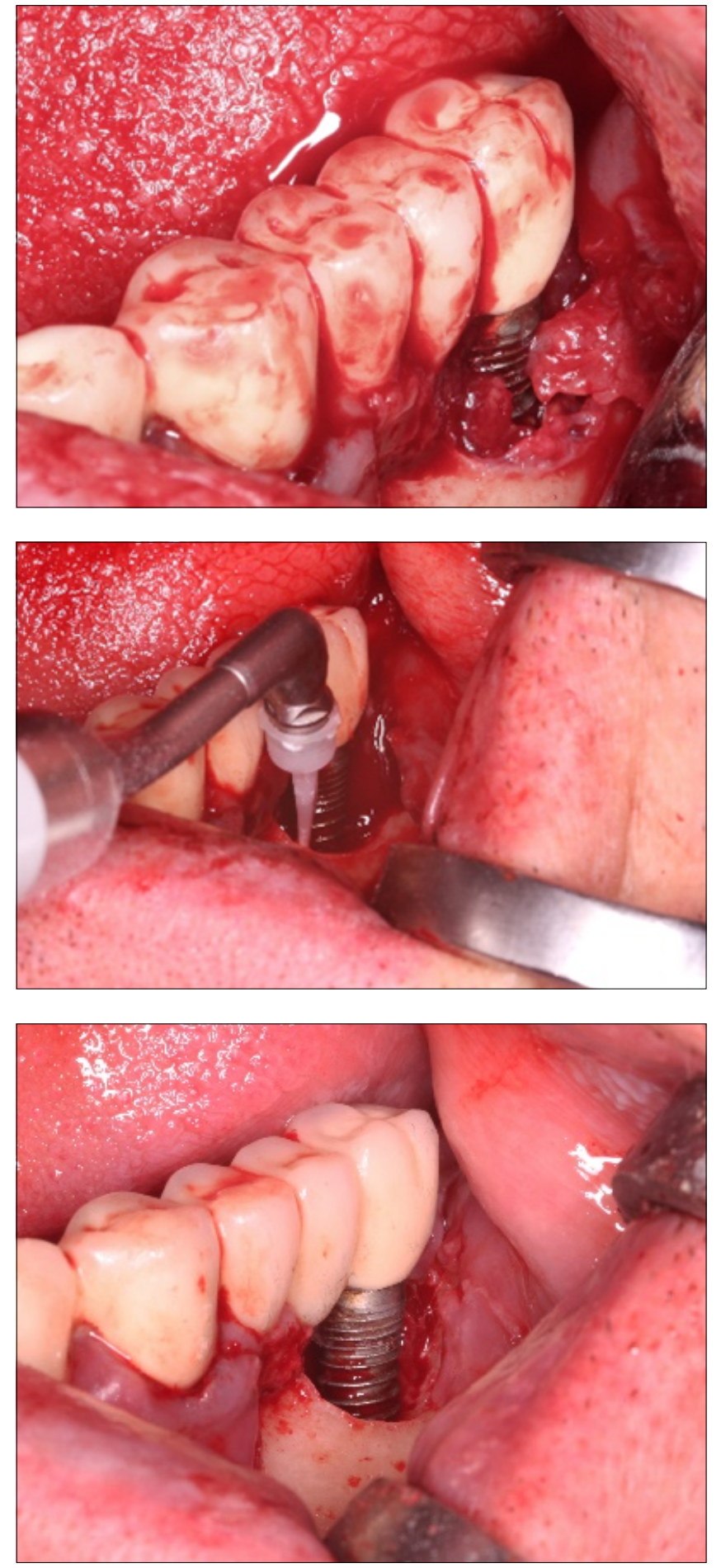

2. kép: NSK Varios Combi Pro alkalmazása periimplantitis esetében

a vízhútés mértékét állíthatjuk. A glicinporos homokfúvás jobban tisztítja az implantátumok felszínét, mint a hagyományos kézi kürettel történő tisztítás, anélkül hogy az implantátum szabad felszíne károsodna [15, 16]. (2. kép)

A tanulmányban lévő betegek klinikai és radiológiai vizsgálaton vettek részt. Klinikai vizsgálatunk során rögzítettük a betegek periimplantaris státuszát az alábbi paraméterek szerint: plakk index $(\mathrm{PI})$, calculus index $(\mathrm{CI})$, szondázási tasakmélység (probing pocket depth, PPD), szondázáskor jelentkező vérzés (bleeding on probing, BoP), gingivalis recessio (GR), keratinizált mucosa szélessége (KM), radiológiai csontveszteség. A betegek kezelési tervét egyénileg alakítottuk ki, de mind a három kezelés során sebészi beavatkozást végeztünk és glicinporos homokfúvóval tisztítottuk meg a kezelt implantátumok felszínét.

\section{1. eset}

66 éves nő páciens a Fogászati és Szájsebészeti Oktató Intézetben jelentkezett a bal alsó molaris régiónál lévő implantátumának ellenőrzésére. A 36, 34 implantátumok lingualis pozíciója miatt a pótlás nehezen tisztítható a beteg számára. A páciens panaszkodott a 36 implantátum nehéz tisztíthatóságára. (3.1. kép) Radiológiai és klinikai vizsgálatunk során periimplantaris gyulladást diagnosztizáltunk a 36 implantátum körül, bár a buccalis oldalt lévő szondázást a pótlás kialakítása miatt nem tudtuk értékelni. (3.2. kép, 3.3. kép) A páciens a pótlását nem szerette volna lecserélni. Kezelési tervünk a 36 implantátum két lépcsőben történő terápiája volt. A páciens magas vérnyomásra szed gyógyszert, nem dohányos, nincs a fogászati kezelést befolyásoló tényezője. Első ülésben az implantátum körüli szövetek zárt submucosalis tisztítása történt a glicinporral múködő, air-abrasive, Varios Combi Pro segítségével. A konzervatív terápiát követően 8 héttel, a keratinizált mucosa szélesítése céljából palatumból nyert szabad ínylebeny (free gingival graft, FGG) átültetését végeztük [17]. A beavatkozásokat 2 perces $0,12 \%$-os klórhexidines öblögetés előzte meg. A mútét során a 36 implantátum buccalis oldalán apicalisan elcsúsztatott félvastag lebenyt képeztünk, majd ezt 6.0-ás varróanyaggal apicalisan a periosteumhoz rögzítettük. (3.4. kép) A palatumból nyert FGG-t 6.0-ás varróanyaggal fixáltuk a 36nál kialakított periosteumágyhoz. (3.5. kép) A páciens instruálásán kívül a beavatkozást követően két hétig klórexidines öblögetést rendeltünk el. A beavatkozást követő 3., 7. és 10. napon kontrolláltuk, majd 14. napon eltávolítottuk a felszínen lévő varratokat. (3.6. kép) A varratszedést követő 1, 3 és 6 hónapnál kontrollra jelentkezett a páciens. A páciens panaszai megszűntek, az implantátuma gyulladásmentes, jobban tisztítható.

\section{2. eset}

68 éves nő páciens az 13 és 14 implantátumoknál lévő visszatérő kellemetlen, feszítő érzés miatt kereste fel a Fogászati és Szájsebészeti Oktató Intézetet. A hölgy érintett implantátumai 2005 környékén kerültek beültetésre. Az 16, 14, 13 és 11 implantátumokon cementtel rögzített fogpótlás volt. (4.2. kép) Klinikai és radiológiai vizsgálataink alapján az 14 és 13 implantátumoknál periimplantitist diagnosztizáltunk. (4.1. kép) 


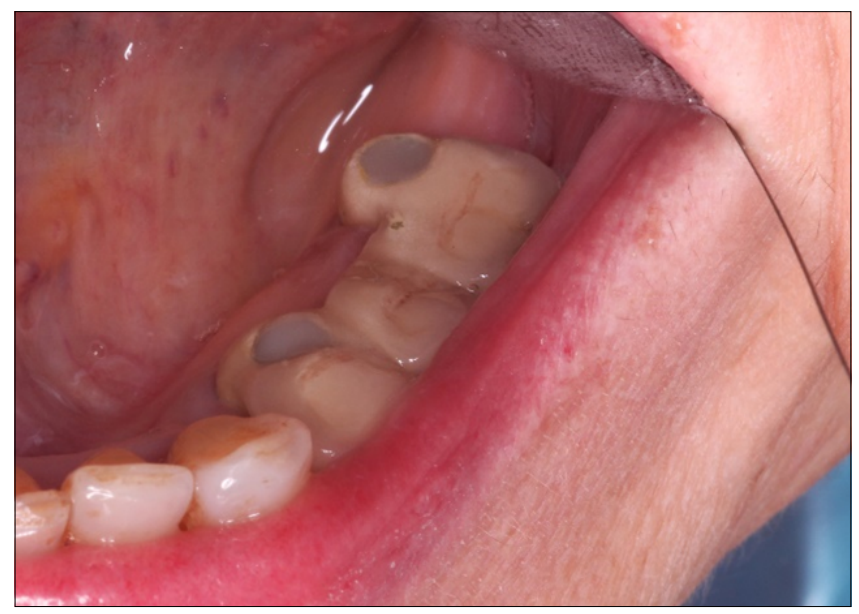

3.1. kép: Az implantátumok protetikai szempontból lingualisan pozícionáltak

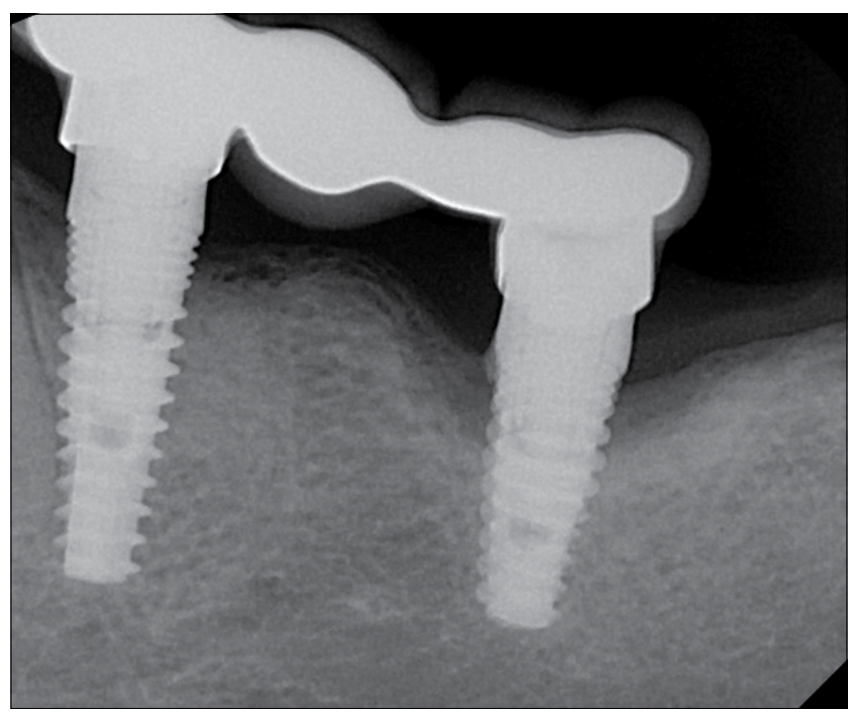

3.3. kép: A 34 és 36 implantátumokról készült intraoralis röntgenfelvétel

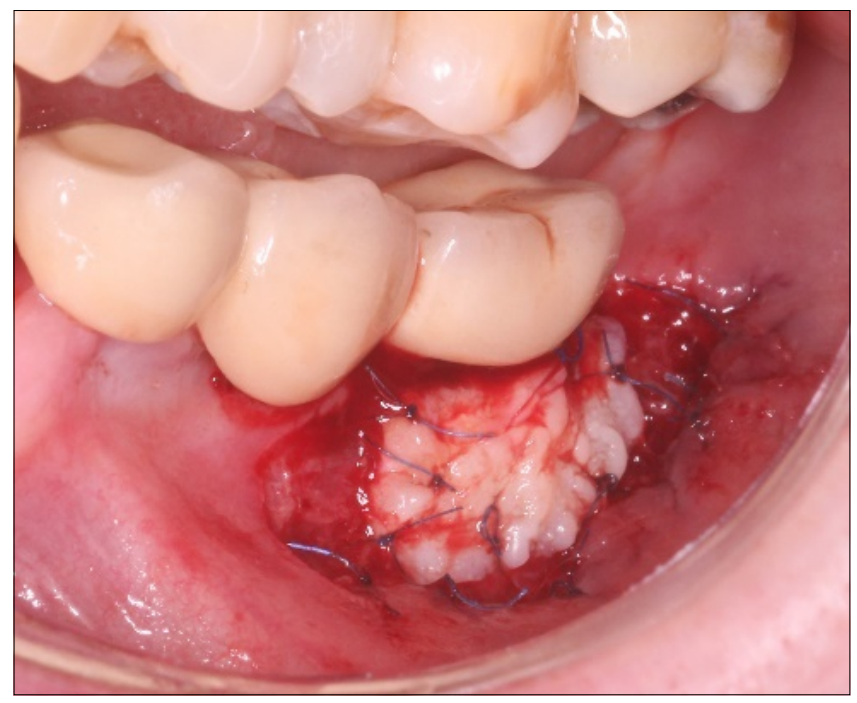

3.5. kép: FGG rögzítését követően

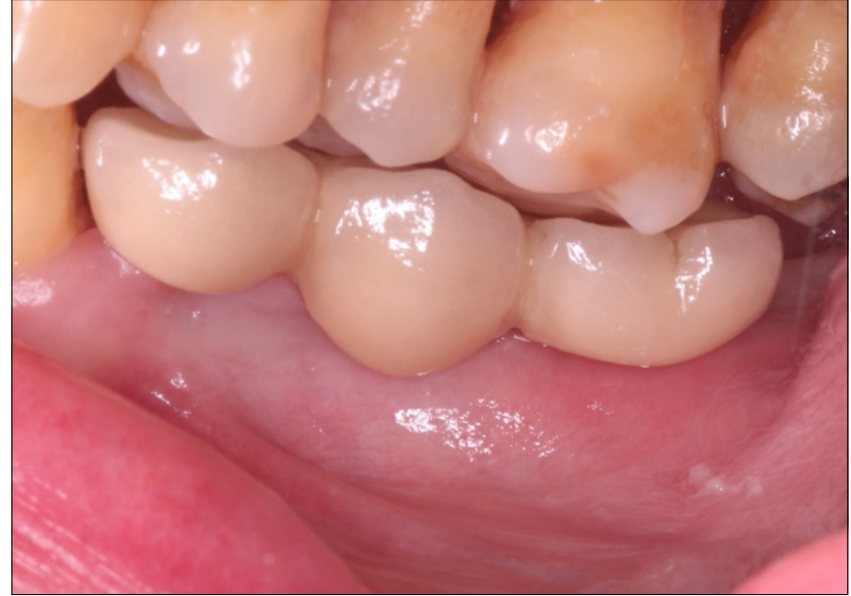

3.2. kép: A 34 és 36 implantátum kiindulási képe buccalis irányból

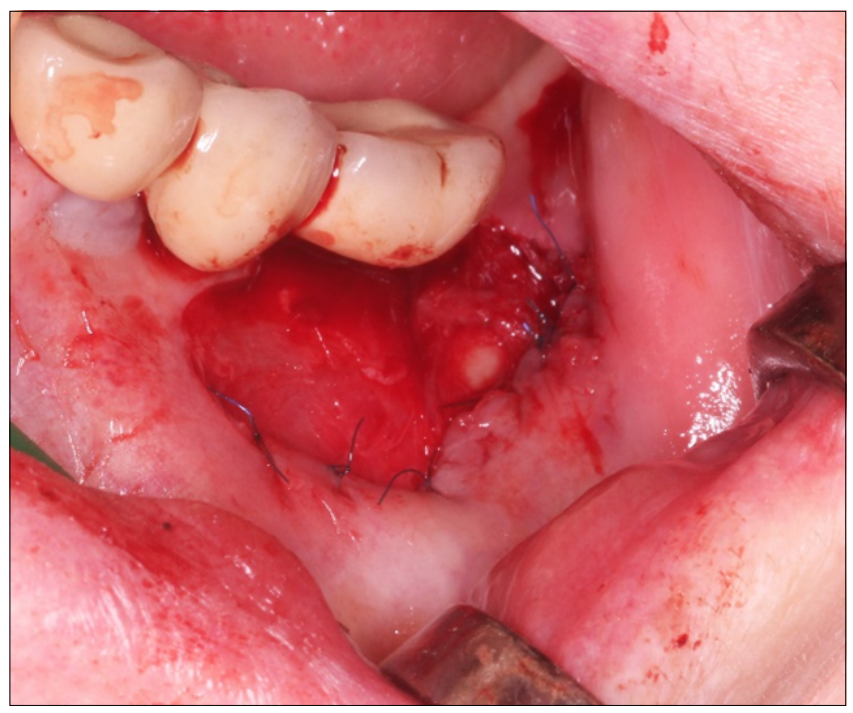

3.4. kép: A 36 területén apicalisan elcsúsztatott félvastag lebeny

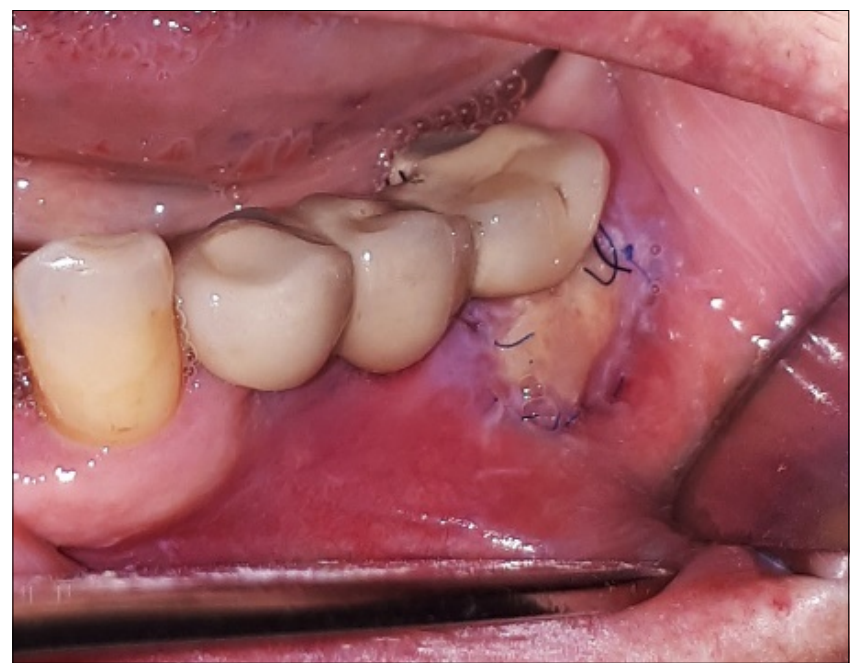

3.6. kép: Egy hetes kontrolnál az átültetett FGG-on fibrinlepedék képződik 
A páciens kórtörténetében kezelt hypertonia szerepelt, a vérnyomáscsökkentőn kívül egyéb gyógyszert nem szedett, nem dohányzott, allergiáról nem tudott. A páciens egyéni szájhigiéniás instruáláson, motiváláson és NSK Varios Combi Pro-val való submucosalis zárt tisztításon átesett. A konzervatív terápiát követő gyógyulási idő elteltével sebészi nyitott küretet indikáltunk. A sebészi beavatkozás előtt 2 percig $0,12 \%$-os klórhexidin-oldattal öblögetett a páciens. 15 fog helyé-

\begin{tabular}{|l|c|c|c|c|c|c|}
\hline A) Kiindulási állapot \\
\hline Implantátum & \multicolumn{7}{|c|}{14} & \multicolumn{3}{c|}{13} \\
\hline & \multicolumn{7}{|c|}{$\begin{array}{c}\text { Buccalis oldal } \\
\text { (D - M) }\end{array}$} \\
\hline Plakk & + & + & + & + & + & + \\
\hline Fogkő & - & - & - & - & - & - \\
\hline PPD & 3 & 5 & 7 & 5 & 4 & 6 \\
\hline GR & 1 & 2 & 1 & 2 & 1 & 1 \\
\hline BoP & + & + & + & - & + & + \\
\hline KW & 3 & 3 & 3 & 4 & 4 & 4 \\
\hline & & & Lingualis oldal & \\
& & & $(D-M)$ & & \\
\hline Plakk & + & + & + & + & + & + \\
\hline Fogkó & - & - & - & - & - & - \\
\hline PPD & 3 & 4 & 4 & 3 & 3 & 3 \\
\hline GR & 0 & 0 & 0 & 0 & 0 & 0 \\
\hline BoP & + & + & + & - & - & - \\
\hline KW & $*$ & $*$ & $*$ & $*$ & $*$ & $*$ \\
\hline
\end{tabular}

\begin{tabular}{|c|c|c|c|c|c|c|}
\hline \multicolumn{7}{|c|}{ B) Féléves kontroll } \\
\hline \multirow[t]{2}{*}{ Implantátum } & \multicolumn{3}{|c|}{14} & \multicolumn{3}{|c|}{13} \\
\hline & \multicolumn{6}{|c|}{$\begin{array}{l}\text { Buccalis oldal } \\
(D-M)\end{array}$} \\
\hline Plakk & + & - & - & - & - & + \\
\hline Fogkő & - & - & - & - & - & - \\
\hline$P P D$ & 3 & 4 & 5 & 4 & 4 & 5 \\
\hline$G R$ & 1 & 2 & 2 & 2 & 2 & 1 \\
\hline$B o P$ & + & - & - & - & - & + \\
\hline \multirow[t]{2}{*}{$K W$} & 3 & 3 & 3 & 3 & 3 & 4 \\
\hline & \multicolumn{6}{|c|}{$\begin{array}{l}\text { Lingualis oldal } \\
(D-M)\end{array}$} \\
\hline Plakk & - & - & - & - & - & + \\
\hline Fogkő & - & - & - & - & - & - \\
\hline$P P D$ & 3 & 4 & 3 & 3 & 3 & 3 \\
\hline GR & 0 & 0 & 0 & 0 & 0 & 0 \\
\hline$B o P$ & - & - & + & - & - & - \\
\hline$K W$ & * & * & * & * & * & * \\
\hline
\end{tabular}

4.1. kép: A páciens kiindulási állapotkor $(A)$ és a beavatkozást követő féléves kontrollnál $(B)$ rögzített periimplantaris státusz eredményei

PPD: szondázási tasakmélység;

GR: gingivalis recessio;

BoP: szondázáskor jelentkező vérzés;

KW: keratinizált íny szélessége;

* palatinalis, keratinizált nyálkahártya) töl induló, 12 fog helyén végződő crestalis metszéssel mucoperiostealis lebenyt képeztünk. A feltárt területről eltávolítottuk a gyulladásos szöveteket, majd az implantátumok szabadon lévő felszínét NSK Varios Combi Pro glicinporos homokfúvóval tisztítottuk. (4.3. kép) A sebet feszülésmentesen zártuk. A varratokat 10 nappal a beavatkozást követően távolítottuk el. (4.4. kép) A páciens féléves kontrollvizsgálatakor a periimplantaris szövetek békések, a 4.1. kép $\mathrm{B}$ részén látható paraméterek alapján a periimplantitis regresszióját figyelhetjük meg.

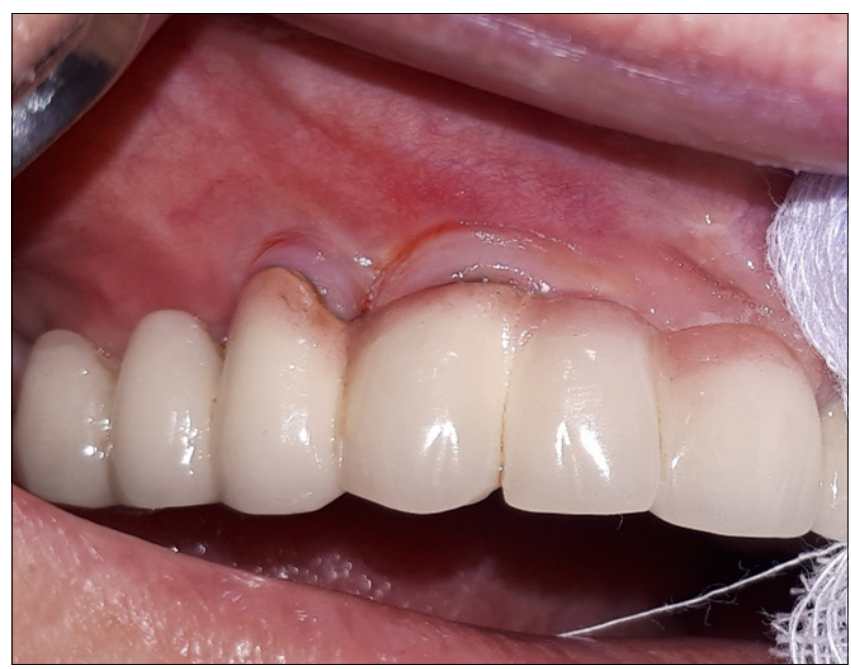

4.2. kép: Az 14 és 13 implantátumokról készített kiindulási buccalis fotó

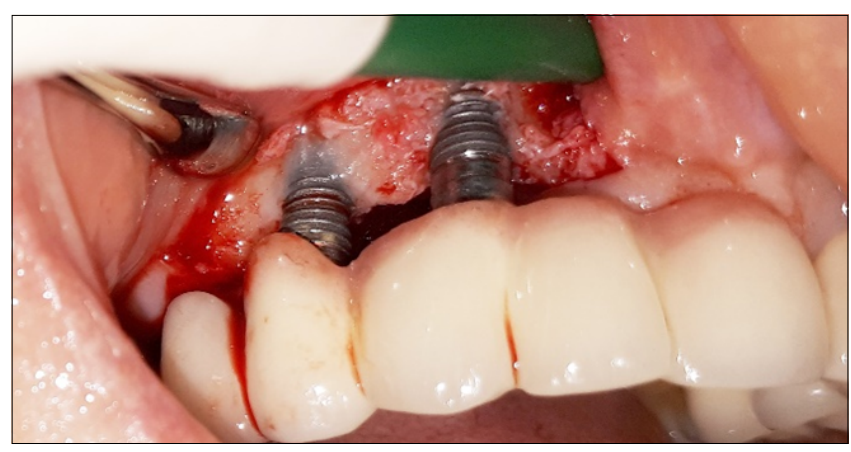

4.3. kép: Az 14 és 13 implantátum nyitott tisztítása

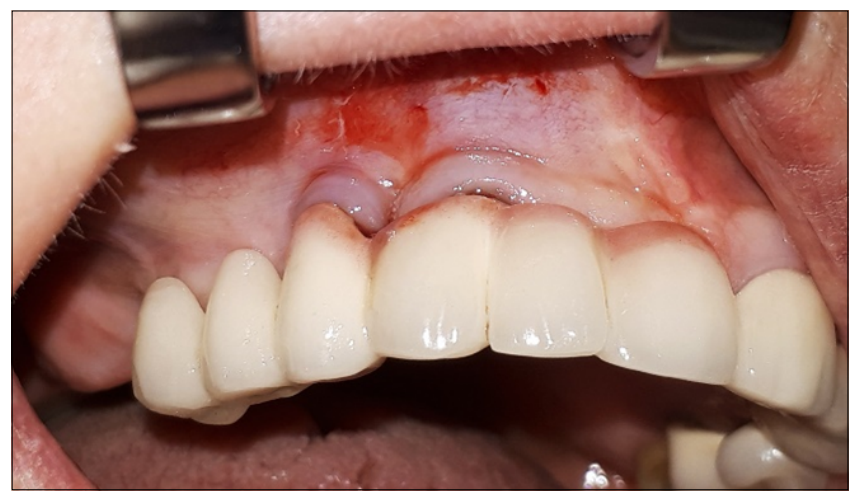

4.4. kép: Varrateltávolítást követően 


\section{3. eset}

69 éves nő páciens kontrollvizsgálatra érkezett Intézetünkbe. A páciens két alsó gömbretenciós implantátuma 2016-ban került beültetésre a Fogászati és Szájsebészeti Oktató Intézetben. A páciens 2017-ben csípőprotézist kapott, gyógyszert nem szed, allergiája nincsen, nem dohányzik. A hölgy fogatlan, a 33 és 43 helyén lévő implantátumokon overdenture típusú fogpótlást visel. A páciens szájhigiéniája nem volt megfelelő. Klinikai és radiológiai vizsgálatunk során a 43 implantátum labialis oldalánál periimplantitist figyeltünk meg. (5.1. kép, 5.2. kép) A 43 implantátumon vastag lepedéket regisztráltunk. A páciens többszöri egyéni szájhigiéniás motiváláson és instruáláson esett át, míg a megfelelő szájhigiéniát elértük. $A z$ implantátum zárt tisztítása után 8 héttel a palatumból nyert FGG átültetését végeztük annak érdekében, hogy a periimplantaris szövetek ellenállóképességét megnöveljük. A sebészi beavatkozást megelőzően a beteg 2 percen keresztül 0,12\%-os klórhexidinnel öblögetett. Félvastag lebenyt preparáltunk, melyet apicalisan a periosteumhoz rögzítettünk, majd a palatumból vett FGG-t 6.0-ás varróanyaggal a periosteumhoz varrtuk. (5.3. kép, 5.4. kép) A pácienst instruáltuk a seb megfelelő ápolására, és a beavatkozást követően két hétig napi kétszeri klórhexidines öblögetést rendeltünk el. A beavatkozást követő 3., 7. és 10. napon a sebet kontrolláltuk, majd a 14. napon eltávolítottuk a felszínes varratokat. (5.5. kép) A varratszedést

\begin{tabular}{|c|c|c|c|c|c|c|}
\hline & \multicolumn{3}{|c|}{ A) Kiindulási állapot } & \multicolumn{3}{|c|}{ B) Féléves kontroll } \\
\hline Implantátum & \multicolumn{3}{|c|}{43} & \multicolumn{3}{|c|}{43} \\
\hline & \multicolumn{6}{|c|}{$\begin{array}{l}\text { Buccalis oldal } \\
(D-M)\end{array}$} \\
\hline Plakk & + & + & + & + & - & - \\
\hline Fogkö & - & - & - & - & - & - \\
\hline$P P D$ & 6 & 5 & 6 & 4 & 4 & 4 \\
\hline GR & 2 & 3 & 2 & 1 & 0 & 1 \\
\hline$B o P$ & + & + & + & - & + & - \\
\hline \multirow[t]{2}{*}{$K W$} & 0 & 0 & 0 & 3 & 3 & 2 \\
\hline & \multicolumn{6}{|c|}{$\begin{array}{l}\text { Lingualis oldal } \\
\quad(D-M)\end{array}$} \\
\hline Plakk & + & + & + & - & - & - \\
\hline Fogkő & - & - & - & - & - & - \\
\hline$P P D$ & 4 & 3 & 2 & 3 & 2 & 3 \\
\hline GR & 0 & 0 & 0 & 0 & 0 & 0 \\
\hline$B o P$ & + & + & + & - & - & - \\
\hline$K W$ & 2 & 2 & 1 & 3 & 2 & 2 \\
\hline
\end{tabular}

5.1. kép: A 43 periimplantaris státusza a páciens kiindulási állapotkor $(A)$ és a beavatkozást követő fél éves kontrollnál $(B)$ rögzített periimplantaris státusz eredményei

PPD: szondázási tasakmélység; GR: gingivalis recesszió;

BoP: szondázáskor jelentkező vérzés; KW: keratinizált íny szélessége követő 1 , 3 és 6 hónapnál kontrollra jelentkezett a páciens. A páciens panaszai megszűntek, az implantátuma gyulladásmentes, jobban tisztítható.

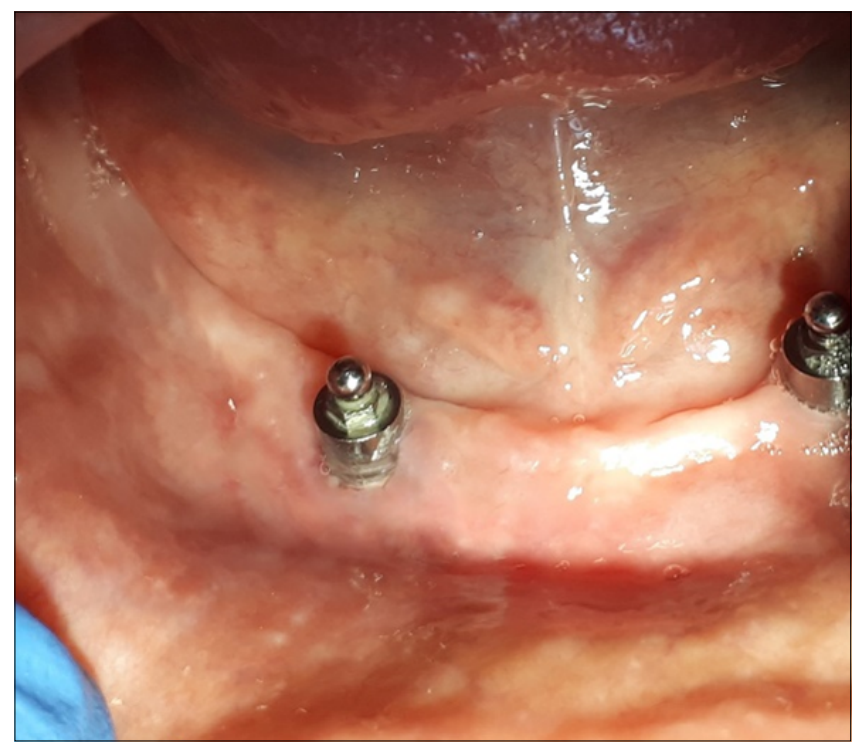

5.2. kép: Kiindulási fotó a 43 implantátumról.

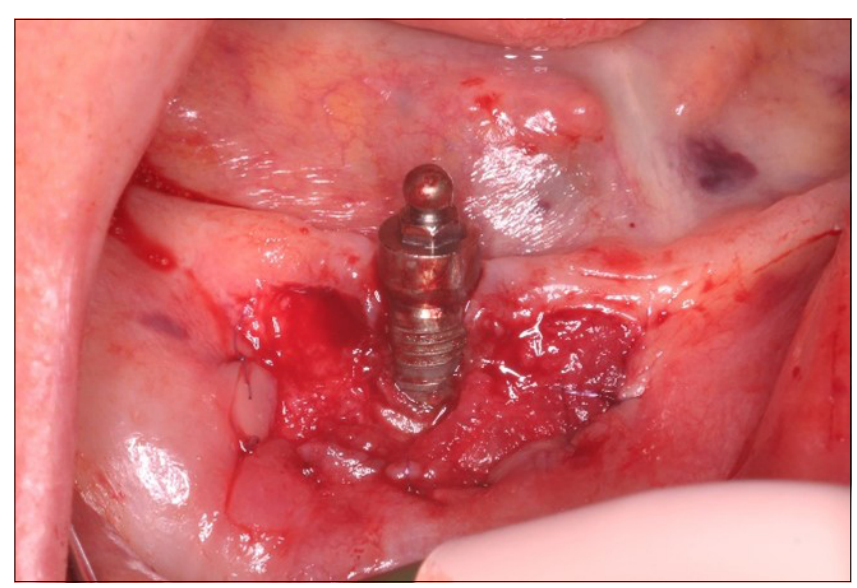

5.3. kép: Apicalisan elcsúsztatott félvastag lebeny

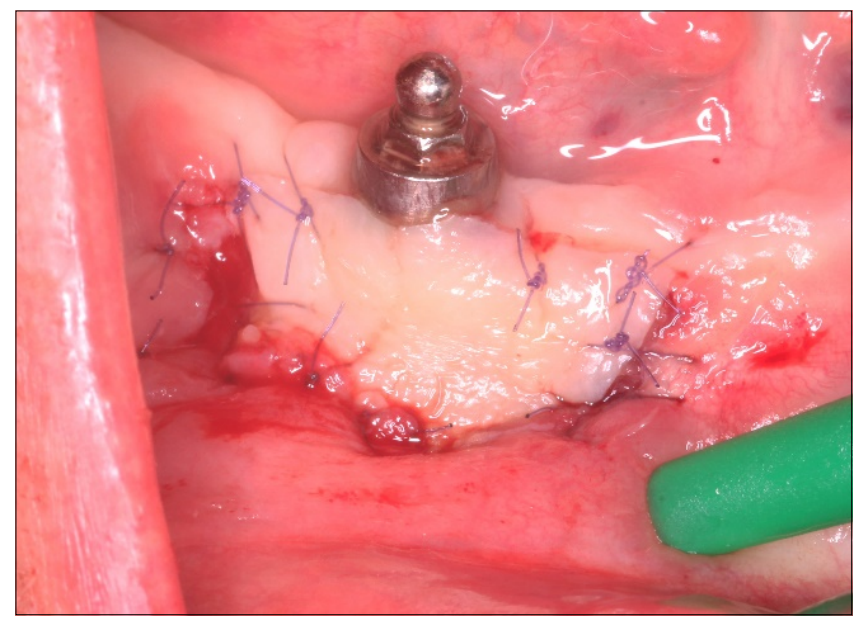

5.4. kép: FGG rögzítése a periosteumágyhoz 


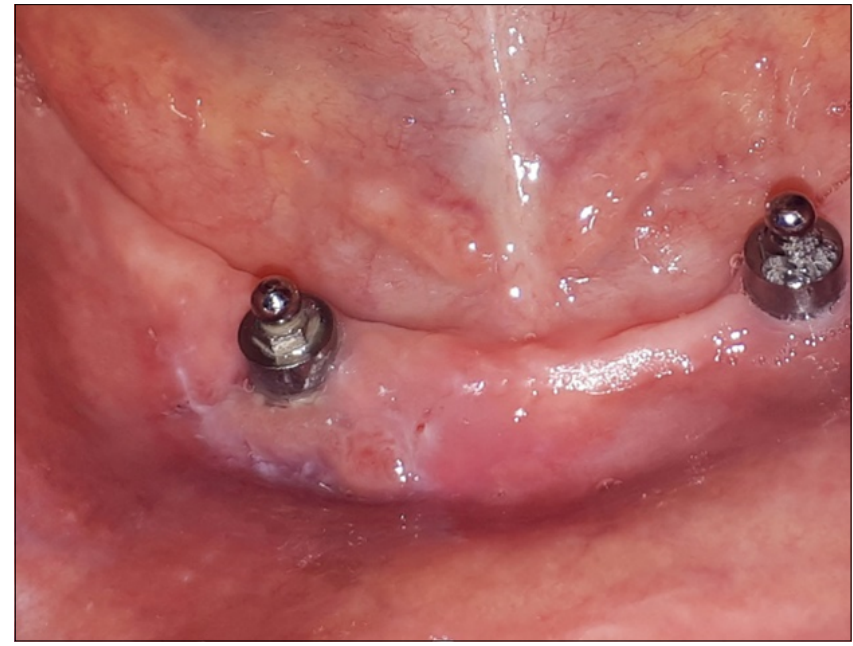

5.5. kép: Varratok eltávolítását követően, a beavatkozás után 15 nappal

\section{Összefoglalás}

Az implantátumok körüli lágy- és keményszövetek gyulladásos folyamatainak kezelésének oki terápiája során elsődleges szerep jut a beteg megfelelő szájhigiénés instruálásának és motiválásának. Fontos a plakkretenciós tényező́k eliminálása a pótlások módosításával vagy a pótlások cseréjével, amennyiben ehhez a betegünk hozzájárul. Mind a konzervatív, mind a sebészi terápia fontos lépése a supraossealis implantátumfelületek dekontaminációja, melynek hatékony eszköze az air abrazív technika.

\section{Irodalom}

1. Bragger U H-ML: ITI Treatment Guide Volume 8. Berlin: Quintessence Publisching Co, 2015.

2. Berglundh T, Armitage G, Araujo MG, Avila-Ortiz G, Blanco J, Camargo PM, et al: Peri-implant diseases and conditions:

Consensus report of workgroup 4 of the 2017 World Workshop on the Classification of Periodontal and Peri-Implant Diseases and Conditions. J Clin Periodontol 2018; 45: S286-91. https://doi.org/10.1111/jcpe.12957

3. Mombell A, Müller N, Cionca N: The epidemiology of peri-implantitis. Clin Oral Implants Res 2012; 23: 67-76.

https://doi.org/10.1111/j.1600-0501.2012.02541.x

4. LindHE J, MeYLE J: Peri-implant diseases: Consensus Report of the Sixth European Workshop on Periodontology.

$J$ Clin Periodontol 2008; 35: 282-285. https://doi.org/10.1111/j.1600-051X.2008.01283.x
5. Klinge B, Meyle J, Claffey N, Flemmig T, Flemming I, Mombelli A, et al: Peri-implant tissue destruction.

The Third EAO Consensus Conference 2012

Clin Oral Implants Res 2012; 23: 108-110. https://doi.org/10.1111/j.1600-0501.2012.02555.x

6. Heitz-Mayfield LJA, Salvi GE: Peri-implant mucositis. J Periodontol 2018; 89: S257-66. https://doi.org/10.1002/JPER.16-0488

7. BoYnUeǦRI D, NemLI SK, KaSKO YA: Significance of keratinized mucosa around dental implants: A prospective comparative study. Clin Oral Implants Res 2013; 24: 928-933. https://doi.org/10.1111/j.1600-0501.2012.02475.x

8. LIN GH, MADI IM: Soft-tissue conditions around dental implants: A literature review. Implant Dent 2019; 28: 138-143. https://doi.org/10.1097/ID.0000000000000871

9. Heitz-Mayfield LJA, Salvi Ge, Botticelli D, Mombelli A, Faddy M, LANG NP: Anti-infective treatment of peri-implant mucositis: A randomised controlled clinical trial. Clin Oral Implants Res 2011; 22: 237-241. https://doi.org/10.1111/j.1600-0501.2010.02078.x

10. Chan H-L, Oh W-S, Ong HS, Fu J-H, Steigmann M, Sierraalta M, et al: Impact of Implantoplasty on Strength of the Implant-Abutment Complex. Int J Oral Maxillofac Implants 2013; 28: 1530-1535. https://doi.org/10.11607/jomi.3227

11. Keeve PL, Koo KT, Ramanauskaite A, Romanos G, Schwarz F, Sculean A, et al: Surgical Treatment of Periimplantitis With Non-Augmentative Techniques. Implant Dent 2019; 28: 177-186. https://doi.org/10.1097/ID.0000000000000838

12. Stavropoulos A, Bertl K, Eren S, Gotfredsen K: Mechanical and biological complications after implantoplasty-A systematic review. Clin Oral Implants Res 2019; 30: 833-848. https://doi.org/10.1111/clr.13499

13. Schwarz F, Schmucker A, Becker J: Efficacy of alternative or adjunctive measures to conventional treatment of peri-implant mucositis and peri-implantitis: a systematic review and meta-analysis. Int $J$ Implant Dent 2015; 1. https://doi.org/10.1186/s40729-015-0023-1

14. Sinjab K, Garaicoa-Pazmino C, Wang HL: Decision making for management of periimplant diseases.

Implant Dent 2018; 27: 276-281. https://doi.org/10.1097/ID.0000000000000775

15. Lupi SM, Granati M, Butera A, Collesano V, Rodriguez Y, Baena R: Air-abrasive debridement with glycine powder versus manual debridement and chlorhexidine administration for the maintenance of peri-implant health status: a six-month randomized clinical trial. Int J Dent Hyg 2017; 15: 287-294. https://doi.org/10.1111/idh.12206

16. Matsubara VH, Leong BW, Leong MJL, Lawrence $Z$, Becker $T$, QuARANTA A: Cleaning potential of different air abrasive powders and their impact on implant surface roughness. Clin Implant Dent Relat Res 2020; 22: 96-104. https://doi.org/10.1111/cid.12875

17. Heitz-MAYFieLd L, of AM-IJ, 2014 undefined: The Therapy of Peri-implantitis: A Systematic Review. Maleeneducation Com 2014. https://doi.org/10.11607/jomi.2014suppl.g5.3 
IVÁnYı D, Simon F, Kivovics M, GÁngó J, NÉmeth O

\section{Surgical peri-implantitis treatment with air-abrasive device}

\section{Case series}

Implant related biological complications include peri-implant mucositis and peri-implantitis. The main clinical symptoms of peri-implant mucositis is bleeding on gentle probing. In case of peri-implantitis, bleeding on probing and increased probing depth are leading signs. Treatments of peri-implant inflammation are divided into conservative and surgical therapies. The prerequisite for both approaches is the proper professional cleaning of supracrestal implant surfaces. According to the literature, air-abrasive technique is suitable for decontamination of contaminated implant surfaces. Silicate-based powders that are suitable for cleaning supramucosal parts are not soluble in aqueous medium, so their use is not recommended submucosally as the small particles cannot be completely eliminated. Using Varios Combi Pro (NSK/Nakanishi Inc., Shimohinata Kanuma, Japan), water-soluble glycine powder can be applied to the implant surface at an adjustable pressure through a disposable special plastic nozzle. During use, the amount of water cooling can be adjusted. Glycine powder air-abrasive technique cleans the surface of implants more efficiently than cleaning with conventional hand curette without damaging supracrestal implant surfaces. Three patients in this case report underwent clinical and radiological examinations. The peri-implant status was recorded by recording the following parameters: plaque index (PI), calculus index $(\mathrm{Cl})$, probing pocket depth (PPD), bleeding on probing (BoP), gingival recession (GR), keratinized mucosa width (KW) and radiological bone loss. Status was also registered at baseline and six months after surgical therapy. Treatment plans of the patients were set up individually, but each treatment involved surgical preparation and air-abrasive debridement with glycine powder with Varios Combi Pro (NSK/Nakanishi Inc., Shimohinata Kanuma, Japan). In two cases, in addition to surgical therapy, free gingival graft (FGG) transplantation was also performed. Peri-implant inflammation was treated successfully in all three cases.

Keywords: Peri-Implantitis, Ari Abrasion, Glycine powder, Debridement 